\title{
ABOUT THE TRANSLATION OF NATURE AND FLORA IN "BOBURNOMA"
}

\section{Feruza Karimova}

Second Year Master's Student, Foreign Language Faculty, Fergana State University, Uzbekistan

\section{ABSTRACT}

This article describes the flora of Boburnoma and their peculiarities in the English translation.

By getting acquainted with the scientific worldview of ecology mentioned in the "Boburnoma", each reader will have a conscious understanding of the wonders of nature, flora and fauna, natural resources, respect for fresh air, protection and transmission to future generations

Our country is one of the oldest centers of civilization in the world. Scientists living and working in the land of ancient Turan have made a great contribution to the development of world history, science and culture. These works are especially revered as immortal monuments of world civilization. One of such monuments known and famous all over the world is Zahiriddin Muhammad Babur's "Boburnoma".

KEYWORDS: - Boburnoma, generations, nature, monuments, geography, plants, garden.

\section{INTRODUCTION}

This work, which is a unique monument of the XVI century, reflects the work of Mirzo Babur not only as a powerful commander, ruler and poet, but also as a natural scientist with mature scientific talent.

Boburnoma "is an encyclopedic work. It contains valuable and reliable information about the history, literature, geography, nature, plants and fauna of Central Asia and India. "Boburnoma" can be called a masterpiece of the scientific heritage of the scientist due to its size and value, the richness and variety of materials, the scope of its information.

Mirza Babur's observations are so clear and figurative that they surpass the data of famous European travelers of the XV-XX centuries with their significance, complete and reliable statements.

He was one of the first in his work to write valuable information about nature and its balance, naming plants and animals, classifying them, acclimatizing plants of different regions, transplanting them from one place to another, and respecting nature. The author of "Boburnoma" pays great attention to the introduction of plants, ie the transplantation, acclimatization and distribution of plant species in places where they have not grown before. This process began worldwide, mainly in the XVI-XVII centuries.

Scientists point out that most of the cultivated plants now grown on all continents of the globe are introducers. In the 16 th and 17 th centuries, corn, potatoes, sunflowers, tomatoes, tobacco, peppers, and other delicacies were imported from America 
CURRENT RESEARCH JOURNAL OF PHILOLOGICAL SCIENCES 2(11):

100-103, November 2021

DOI: https://doi.org/10.37547/philological-crjps-02-11-22

ISSN 2767-3758

(C2021 Master Journals

\section{Crossref do:}

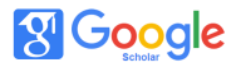

Accepted $25^{\text {th }}$ November, 2021 \& Published $30^{\text {th }}$ November, 2021

to Europe. Sugarcane was introduced to America from Southeast Asia via the Canary Islands. Plums, apples, pears, chestnuts and other trees imported from Europe have been grown in America since the 17 th century.

When plants are moved from their natural habitats to new areas, its traits, which are considered economically valuable, have improved.

\section{Methods}

That is, there is an increase in productivity, an increase in plant weight, an increase in resistance to various diseases and pests. Central Asia is also the center of origin of a number of cultivated plants. However, in the 16th century and earlier, plants unknown to Central Asia were also brought to Central Asia. One such plant is sugar cane. It was brought from India through the Kabul province of Afghanistan to the Denau and Sariosiya districts of the present-day Surkhandarya province. Readers of the Boburnoma will see that the introduction of plants in Central Asia, as in other continents, began in the XVI century.

But there is no information about it in scientific and educational literature. Some scholars believe that the opening of sea routes from Europe to India and China restricted the entry of new, rare and exotic plants into Central Asia, making it impossible to bring plants not only from America and Europe but also from neighboring countries due to the dispersal of Central Asian khanates.

In 1514, Babur created a large garden south of the Odinapur Fortress (Kabul Province) called the Garden of Faith. In the same year, he defeated Pahor Khan, captured the cities of Lahore and Dibolpur, brought bananas from there, and planted them in the Garden of Faith.

Bananas give a good harvest. A year earlier, he had planted sugar cane in the garden. It also grows well. After that he sent sugar cane to Bukhara and Badakhshan. At that time, the latitudes of Badakhshan and Bukhara were connected in Denau and Sariosiya. That is why the natural sugar cane fields of Denau and Sariosia were preserved until the Soviet era. During the former empire, a sugar cane farm was established here, and rum was produced from its raw materials at the Samarkand winery. So, we should be grateful to our great compatriot for the fact that sugar cane growing in the southern regions of Uzbekistan was first introduced by Babur in the XVI century.

Mirza Babur distributed the plants not only from south to north, but also from north to south. "Kabul and the city are rich in grapes and pomegranates, apricots and apples, quinces and pears, peaches and plums, almonds and walnuts. I planted olu-bolu (mountain cherry) seedlings, they have good mountain cherries and they are still developing, "he said. According to the Boburnoma, roses, melons and grapes were also introduced to India. In 1526, Babur conducted the first experiments with Central Asian melons and grapes in the garden of KabulBakht in Panipat. He said that a Balkh farmer invited a farmer and ordered him to plant a melon In his memoirs, Babur writes that he was very happy that melons and grapes in India produced such a good harvest. NK Pandit, a professor at the University of Kashmir, and poet A. Bismillah, who attended a conference in Tashkent in 1988, testified that the Anguri Samarkand variety was still grown in India.

It is acknowledged in science that the plants were introduced by the Swedish biologist K. Linney, who called the plants by a double name, i.e. white birch, black willow. It is also recognized that $\mathrm{K}$. Linney discovered that plants have sexual reproduction as well as animals. However, it was during this period that Babur (1483-1530) also referred to some 
CURRENT RESEARCH JOURNAL OF PHILOLOGICAL SCIENCES 2(11):

100-103, November 2021

DOI: https://doi.org/10.37547/philological-crjps-02-11-22

ISSN 2767-3758

(C2021 Master Journals

\section{Crossref do:}

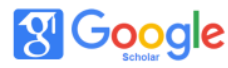

Accepted25th November, 2021 \& Published $30^{\text {th }}$ November, 2021

plants by double names.

According to Babur, there is a place called "Dashti Sheikh" in Gurband district near Kabul, where spring is very good and a variety of tulips grow. Bobur orders a list of varieties of tulips. It turns out that there are thirty-two to thirty-three different tulips. Because of the smell of a red flower from a variety of tulips, Bobur suggests calling it "Lolai gulboy".

According to Babur, there is a place called "Dashti Sheikh" in Gurband district near Kabul, where spring is very good and a variety of tulips grow. Babur orders a list of varieties of tulips. It turns out that there are thirty-two to thirty-three different tulips. Because of the smell of a red flower from a variety of tulips, Bobur suggests calling it "Lolai gulboy". It is said that this type of tulip is found in one part of "Dashti Sheikh" and will not die in other places. Below this place, on the way out of Gurban, there is another type of tulip. It is called Lolai Sadbarg.

\section{Discussion}

This tulip is also found only in one place. Almost all the trees and grasses mentioned in the Boburnoma have double names. For example, aspen tail, blueberry, cocaine, sebi Samarkand, pomegranate donakalon and so on.

In some cases, Babur tried to write the names of plants in one word in two words: "In Andijan region, this grass is called idol grass.

Babur was in almost every city in Central Asia. He described the climatic conditions of the places and the cleanliness of the environment. He writes: "One of the cities of Fergana is Osh. The air is clean and there is a lot of running water. The spring will be very good, the Andijan river will pass through the mahallas of Osh and go to Andijan. There are many gardens on both sides of this stream. The gardens are joined by a stream, the purple flowers are very delicate, there is running water, the spring is very good, the thick tulips and flowers open. There is no city in the Fergana region like Osh.

Kosonsoy is also well described in the Boburnoma.

\section{Conclusion}

He writes that the air in Kosonsoy is good, there are many gardens, and the gardens are mostly on the banks of the river, so the "skin is like five bars", that is, it is like a skin decorated with astrakhan leather. The poet connects the purity of the air with the abundance of gardens and vineyards. “... Andijan's food will be wafir, its fruits will be abundant, melons and grapes will be very good. There is no better noshpot than Andijan noshpotis. " However, because the air in Andijan is not clean, many people get malaria in the fall. Wherever Babur went, he scientifically described the nature of the land, the diversity of its flora and fauna. By getting acquainted with the scientific worldview of ecology presented in the "Boburnoma", each reader will gain a conscious understanding of the wonders of nature, flora and fauna, natural resources, respect for fresh air, protection and transmission to future generations.

An in-depth analysis of this encyclopedic work also serves as an important historical source in the study of the history of natural sciences, biology and ecological sciences. We believe that the study and analysis of the Boburnoma from this point of view also puts on the agenda the creation of the Bobur encyclopedia.

\section{ReFERENCES}

1. Zahiriddin Muhammad Bobur. “ 
CURRENT RESEARCH JOURNAL OF PHILOLOGICAL SCIENCES 2(11):

100-103, November 2021

DOI: https://doi.org/10.37547/philological-crjps-02-11-22

ISSN 2767-3758

(C)2021 Master Journals

crossref do) 8: Google

Accepted25 $5^{\text {th }}$ November, 2021 \& Published $30^{\text {th }}$ November, 2021

Boburnoma". Toshkent,1989.

2. Rasuljanovna, I. N. (2020). The concept of "lacuna" in translation studies. Asian Journal of Multidimensional Research (AJMR), 9(4), 123-129.

3. Khudoyorovich, K. K., Rasuljanovna, I. N., Khalmuratovna, R. Z., \& Eshkobilovna, K. D. (2020). The Issues of Word Choice in Fiction Translation. International Journal of Psychosocial Rehabilitation, 24(04).

4. Ismatullayeva, N. R. Translation of phraseological units in Chinese and Uzbek languages. In Scientific research of the SCO countries: synergy and integration (International conference). Beijing, PRC, June (Vol. 24, pp. 45-50).

5. Linklar:

6. http:// google.ru

7. http://wikipedia. org 